\title{
Variation of allozyme frequencies in Spanish field and cellar populations of $D$. melanogaster
}

\author{
Angeles ALONSO-MORAGA *, A. MUÑOZ-SERRANO and A. RODERO \\ * Departamento de Genética, Facultad de Veterinaria, Universidad de Córdoba, \\ Av. Medina Azahara 9, 14005 Córdoba, Spain
}

\begin{abstract}
Summary
Polymorphism at the $A d h, \alpha-G p d h$ and Est-6 loci have been studied in 12 populations from the Southern Iberian peninsula, coming from different environments in which alcohol is absent or present (fields and wine cellars). FINETTI diagrams, analyses of linkage disequilibrium and analyses of gene frequencies show that the determining locus for the genetic variation in these populations is $A d h$. Neither the $\alpha-G p d h$ locus, which is on the same chromosome as the Adh locus (2L), nor the Est-6 locus is influenced by different environments in which the determining factor is the presence or absence of alcohol in the medium.
\end{abstract}

Key words : Drosophila melanogaster, allozyme polymorphism (Adh, $\alpha-G p d h$, Est-6), ecological niches, alcohol.

\section{Résumé}

Variation des fréquences alloenzymatiques de populations espagnoles de $\mathrm{D}$. melanogaster provenant de celliers et de la campagne

Le polymorphisme des locus $A d h, \alpha-G p d h$ et Est-6 a été étudié dans 12 populations de Drosophila melanogaster provenant du sud de la péninsule ibérique. Ces populations vivent dans différents milieux, caractérisés par la présence (populations de caves) ou l'absence (populations de campagne) d'alcool. Les diagrammes de FineTrI, l'analyse des déséquilibres de liaison et des fréquences alléliques montrent que le locus $A d h$ est déterminant dans la variation génétique des 12 populations analysées. Ni le locus $\alpha$-Gpdh (sur le même chromosome que l'Adh), ni l'Est-6 ne sont influencés par la présence ou l'absence d'alcool du milieu.

Mots clés : Drosophila melanogaster, polymorphisme alloenzymatique (Adh, Est-6, $\alpha-G p d h)$, niches écologiques, alcool.

\section{Introduction}

Some ecological models such as those of LEvENE (1953) and Li (1955) have been proposed to explain the maintenance of allozyme polymorphism. LEwonTIN et al. (1978) considered that stable equilibrium in a multiallelic locus is better explained by multiple 
niche slection than by heterotic models. Another solution is to consider that most genetic variation is selectively neutral (KIMURA, 1979). The former explanations might be inferred for enzymes with exogenous substrates when the populations are living in habitats with little or none of these substrates, as has been seen at the Adh locus in environments without alcohol (DAgGard, 1981 ; Hickey \& McLeAN, 1980).

The difference in the $A d h$ locus polymorphism between field and wine-cellar populations have been previously studied by Hickey \& McLean (1980) and by Parsons (1980) ; these authors have used a single wine-cellar population for reference and have not taken into account any other loci, in order to test whether the differences are due to the complete 2 nd chromosome or to the background, as evidenced by Pieragostini et al. (1981). Thus, in this paper we have analyzed the polymorphism in field and winecellar populations at the $A d h$ locus (2-50.1), and simultaneously at 2 other loci, one on the same chromosome as $A d h(\alpha-G p d h ; 2-20.5)$, the other on the third chromosome (Est-6; 3-36.8). The main difference between the 2 environments (field and winecellars) is the presence or absence of alcohol.

\section{Material and methods}

We have sampled 12 populations in the Southern Iberian peninsula. The first nine were taken from wine-cellars; sample 10 was taken near a wine-cellar site (outside the building where the wine is stored). Samples 11 and 12 were respectively captured in a city and in an orchard zone ; both were at least $500 \mathrm{~m}$ from the nearest wine-cellars (see figure 1).

The samples (100 random individuals per population) were taken in July and analyzed electrophoretically for the $A d h, \alpha-G p d h$ and Est-6 loci. We have used horizontal starch gel electrophoresis and the techniques of O'Brien \& McINTYRE (1969) for Adh, O'Brien \& McInTYRe (1972) for $\alpha$-Gpdh and Poulik (1957) for Est-6.

For the statistical study, we have followed the analyses of gene frequencies proposed by CocKerham (1973), who extended the variance component concept to include the components : $\sigma_{w}^{2}$ due to variation of genes within individuals $\sigma_{b}^{2}$ due to variation of genes between individuals within subpopulations $\sigma_{a}^{2}$ due to differences among subpopulations. These 3 components sum to the total variance $\sigma^{2}$. The different correlations are estimated as ratios of the estimates of components of variance : (1) correlation between genes within individuals $F=\left(\sigma_{a}^{2}+\sigma_{b}^{2}\right) / \sigma^{2} ;(2)$ correlation between genes of different individuals in the same subpopulation $\theta=\sigma_{a}^{2} / \sigma^{2}$ and (3) correlation between genes within individuals within subpopulations $f=\sigma_{b}^{2} /\left(\sigma_{w}^{2}+\sigma_{b}^{2}\right)$. These parameters $\mathrm{F}, \theta$ and $f$ correspond to WrIGHT's (1969) $\mathrm{F}$ statistics $\mathrm{F}_{\mathrm{IT}}, \mathrm{F}_{\mathrm{ST}}$ and $\mathrm{F}_{\mathrm{IS}}$ respectively. For estimation of linkage disequilibrium, a measure of disequilibrium formed by the union of gametes $A_{i} B_{j}$ and $A_{k} B_{l}$ was suggested by Burrows (COCKERHAM $\&$ WEIR, 1977). This measure is the partition of the usual linkage disequilibrium into 2 components : $\mathrm{D}_{i j}^{b}$, between-individual and $\mathrm{D}_{i j}^{w}$, within individuals ; $\Delta_{i j}=\mathrm{D}_{i j}^{w}+2 \mathrm{D}_{i j}^{b} \cdot \tilde{\Delta}_{i j}$ has an unbiased estimate in samples of $\mathrm{N}$ individuals : $\Delta_{i j}=\mathrm{N}\left(\tilde{\mathrm{P}}_{. .}^{i j}+\tilde{\mathrm{P}}_{. j}^{i . j}-2 \tilde{p}_{i} \tilde{q}_{j}\right) /(\mathrm{N}-1)$. Correlation coefficients based on BuRRows', $\tilde{\Delta}_{i j}$, are given by the formula :

$$
\mathbf{R}_{i j}=\tilde{\Delta}_{i j} / \sqrt{\left[\tilde{p}_{i}\left(1-\tilde{p}_{i}\right)+\tilde{\mathbf{D}}_{i .}^{\left.i_{i}\right]}\left[\tilde{q}_{i}\left(1-\tilde{q}_{i}\right)+\tilde{\mathrm{D}}_{. j}^{\cdot j}\right]\right.}
$$




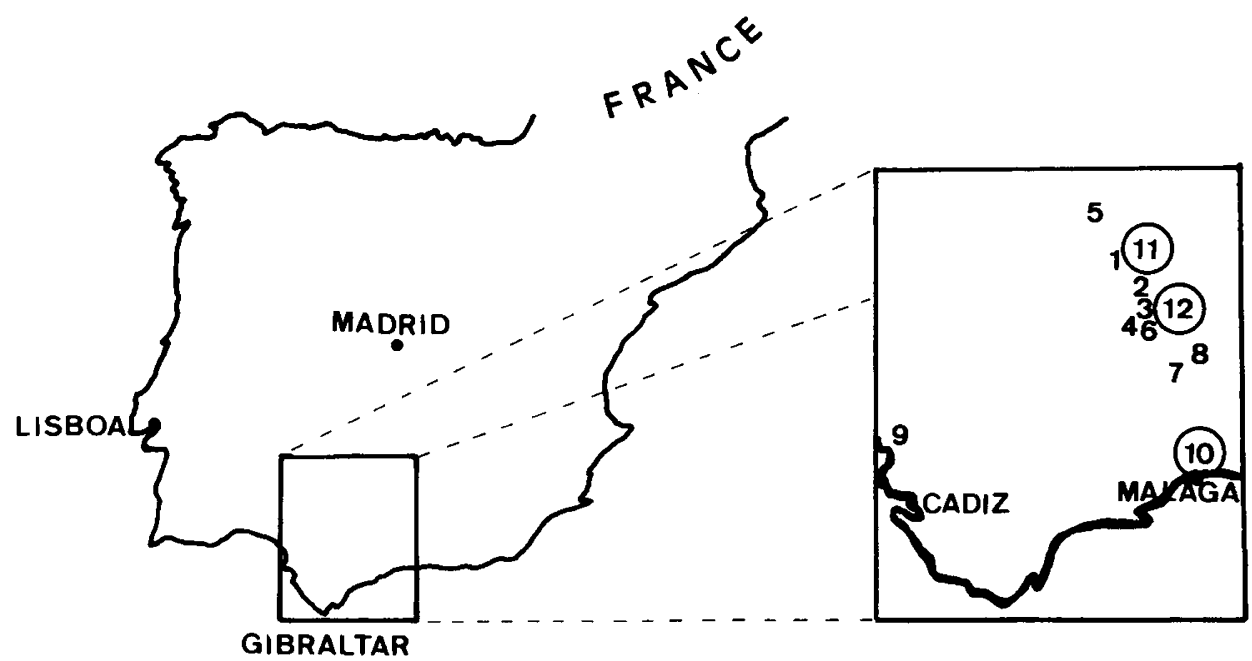

FIGURE 1

Geographical location of the 12 populations sampled. Scale $1: 28 \times 10^{6}$. Localisation géographique des 12 populations analysées. Echelle $1: 28 \times 10^{6}$.

Wine-cellar populations / Populations de caves à vin.

1: Córdoba. 2: Fernan Núñez. 3 : Montemayor. 4 : La Rambla. 5 : Villaviciosa. 6 : Montilla. 7: Lucena. 8: Doña Mencia. 9 : Sanlucar de Barrameda.

Field populations / Populations de campagne.

(11) : Málaga. (12) : Córdoba. (13): Montemayor.

This measure incorporates the departures from Hardy-Weinberg equilibrium for the frequencies at each locus, and is discussed by WEIR (1979). The null hypothesis is tested by : $\chi^{2}=\mathrm{N}\left(\tilde{\Delta}_{i j}\right)^{2} / p_{i}\left(1-p_{i}\right) p_{j}\left(1-q_{j}\right)$.

\section{FII. Results and discussion}

Figure 2 shows the FinerTI diagrams for each locus analized. We can observe that the $A d h^{\mathrm{F}}$ is predominant in wine-cellar populations, and less common in field populations. For $\alpha-G p d h$, it clearly appears that populations 10,11 and 12 are in the same zone of the diagram, but the difference between wine-cellar and field populations is less pronounced; the same can be observed for Est-6. The Adh locus shows (tabl. 1) a greater excess of homozygotes (over Hardy-Weinberg expectations) in the field populations than in the cellar populations, followed by the $\alpha-G p d h$ locus. 
Adn
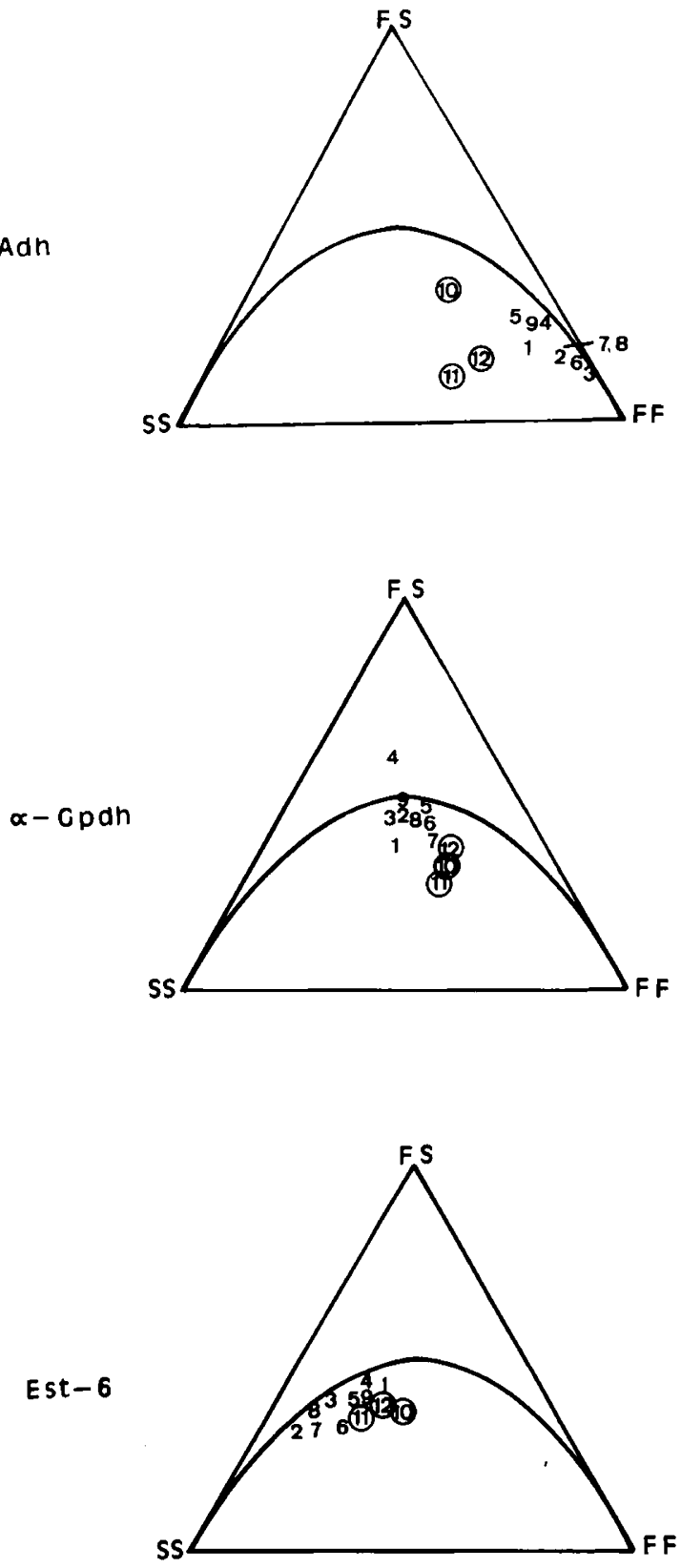

Field populations.

Populations de campagne.

Figure 2

FINETTI diagrams for the 3 loci analyzed.

Diagrammes de FINETTI pour les 3 loci analysés. 
TABLE 1

Genotypes (FF, FS, SS), allelic frequencies (p) and $\chi^{2}$ values in Hardy-Weinberg expectations. Effectifs des génotypes (FF, FS, SS), fréquences alléliques (p) et valeurs du $\chi^{2}$ de conformité à la loi de Hardy-Weinberg.

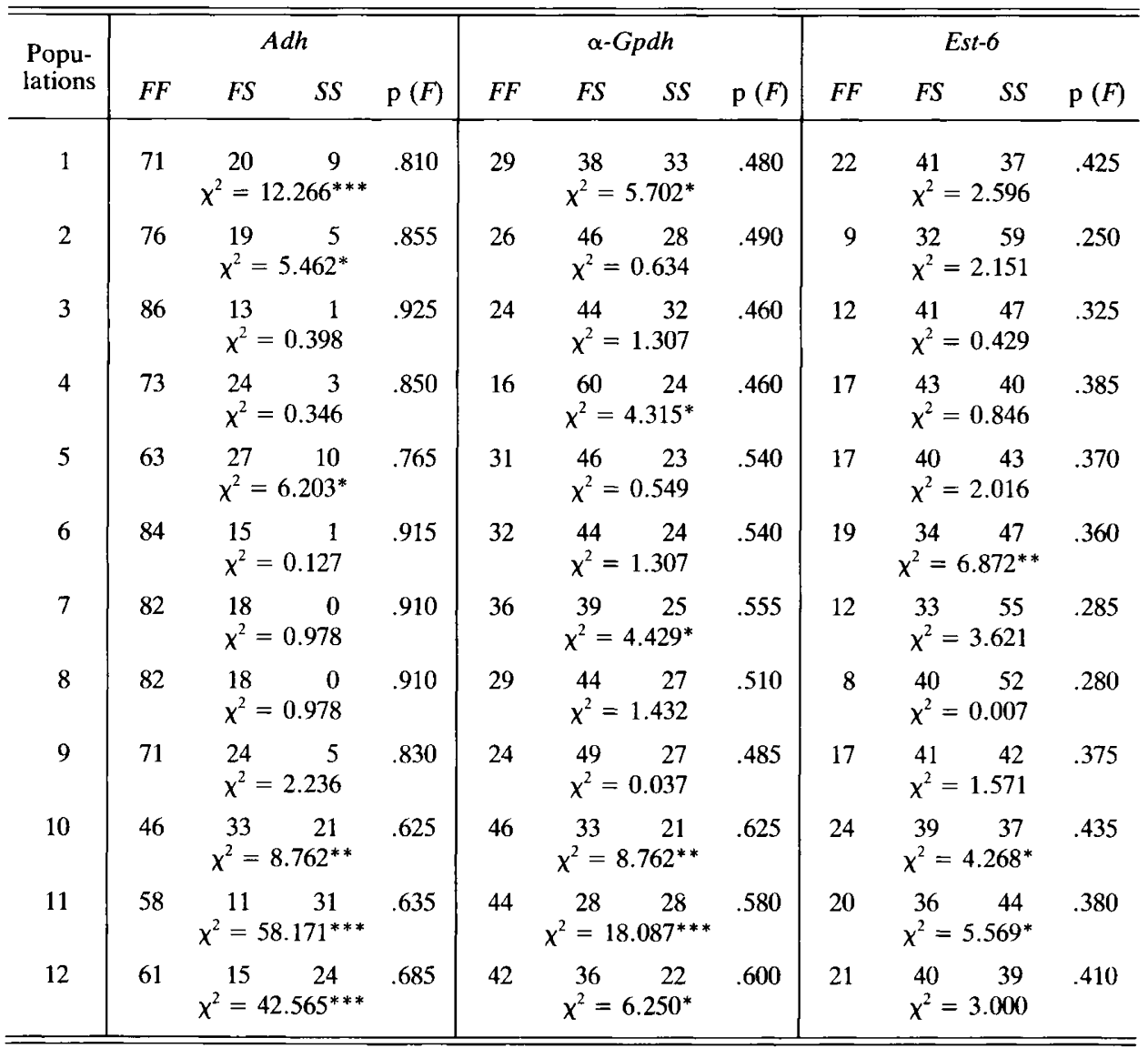

$* \mathrm{p}<0.05$.

${ }^{* *} \mathrm{p}<0.01$

*** $\mathrm{p}<0.001$.

All of the $\chi^{2}$ have one degree of freedom.

Table 2 gives the results of the analysis of gene frequencies following the method of Cockerham (1973). The values of $\mathrm{F}, \theta$ and $f$ corresponding to the Est-6 and $\alpha-G p d h$ loci are practically equal; but those of the $A d h$ locus are higher than for the other two. The $\theta$ coefficient (correlation between genes of different individuals within a subpopulation) is 7 times greater or more for the $A d h$ locus than for the other 2 loci, while $\mathrm{F}$ (correlation between genes within individuals) and $f$ (correlation between genes in individuals within a subpopulation) are more than double for the $A d h$ locus. This indicates that the among-subpopulations component of variance corresponds to 7 p. 100 of the total variance for the $A d h$ locus, while it corresponds to $0.65 \mathrm{p} .100$ and $0.97 \mathrm{p}$. 
TABLE 2

Values of $F, \theta$, and $\mathrm{f}$ for the analysis of gene frequencies, using the COCKERHAM's method (1973). Valeurs de $F, \theta$ et $\mathrm{f}$ dans l'analyse des fréquences génétiques, selon la méthode de CocKerHam (1973).

\begin{tabular}{|c|c|c|c|}
\hline Locus & F & $\theta$ & $f$ \\
\hline$A d h$ & 0.3635 & 0.0705 & 0.3152 \\
\hline$\alpha-G p d h$ & 0.1534 & 0.0065 & 0.1478 \\
\hline Est-6 $\ldots \ldots \ldots \ldots \ldots$ & 0.1658 & 0.0097 & 0.1576 \\
\hline
\end{tabular}

100 for the $\alpha-G p d h$ and Est-6 loci respectively. The sum of among-subpopulations and between-individuals components of variance corresponds to 36.35 p. 100 for $A d h, 15.34$ p. 100 for $\alpha-G p d h$ and 16.58 p. 100 for Est-6.

In most populations in this study, we find a significant linkage disequilibrium in the repulsion phase between $A d h$ and $\alpha-G p d h$ loci (tabl. 3). Aguade \& Serra (1980), MALPICA \& VASAllo (1980) have obtained the same result in natural populations from the Iberian peninsula. When such associations of non-allelic genes in gametes are found in many populations, it may be concluded that selection is acting on these populations, it may be concluded that selection is acting on these populations (LEwonTIN, 1974). These results, considered in their entirely, may indicate that selective forces are acting on the $A d h / \alpha-G p d h$ gamete.

TABLE 3

Values of linkage disequilibrium for pairs of loci.

Valeurs du déséquilibre de liaison pour différentes paires de loci.

\begin{tabular}{|c|c|c|c|}
\hline Populations & $A d h / \alpha-G p d h$ & Adh/Est-6 & $\alpha-G p d h / E s t-6$ \\
\hline $1 \ldots \ldots \ldots \ldots$ & $-0.26938^{* *}$ & -0.07696 & 0.12618 \\
\hline $2 \ldots \ldots \ldots \ldots \ldots$ & $-0.21332^{*}$ & -0.09748 & 0.12582 \\
\hline 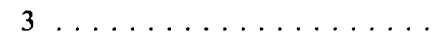 & -0.14846 & 0.02885 & 0.12310 \\
\hline $4 \ldots \ldots \ldots$ & $-0.29126^{* *}$ & -0.08647 & 0.00358 \\
\hline $5 \ldots \ldots \ldots \ldots$ & -0.14939 & -0.14915 & 0.05837 \\
\hline $6 \ldots \ldots \ldots \ldots$ & $-0.22459^{*}$ & -0.05808 & 0.12888 \\
\hline $7 \ldots \ldots \ldots$ & -0.10269 & 0.08531 & 0.03245 \\
\hline $8 \ldots \ldots \ldots \ldots \ldots$ & -0.05764 & -0.07919 & -0.02372 \\
\hline $9 \ldots \ldots \ldots \ldots \ldots \ldots \ldots \ldots \ldots$ & $-0.29876^{* *}$ & 0.06105 & -0.07309 \\
\hline $10 \ldots \ldots \ldots \ldots \ldots$ & $-0.50297^{* * *}$ & $-0.28790^{* *}$ & 0.16935 \\
\hline $11 \ldots \ldots \ldots \ldots \ldots$ & $-0.46022^{* * *}$ & $-0.24189^{*}$ & $0.23571^{*}$ \\
\hline $12 \ldots \ldots \ldots \ldots \ldots \ldots \ldots \ldots \ldots \ldots \ldots \ldots$ & $-0.31502^{* *}$ & $-0.33882^{* * *}$ & 0.13155 \\
\hline
\end{tabular}

\footnotetext{
* $\mathrm{p}<0.05$.

** $\mathrm{p}<0.01$.

$* * * \mathrm{p}<0.001$.
} 
The higher values of $\theta$ and $F$ at the $A d h$ locus indicate that the 12 populations analyzed are very heterogeneous for this locus. Moreover, the pronounced deviation of the $A d h$ locus from Hardy-Weinberg equilibrium in populations 10, 11 and 12 (due to an excess of homozygotes) and the disequilibrium found in these 3 populations for the gametes $A d h / \alpha-G p d h$ and $A d h / E s t-6$ may indicate that the field populations are indeed a mixture of subpopulations with high variance between individuals $\left(\sigma_{b}^{2}\right.$ and $\left.D_{i j}^{b}\right)$. This could be interpreted to mean that, in fields, the nutritive substrates are more heterogeneous than in wine-cellars and produce differential selection. Thus, there are some ecological niches where the $A d h$ genotypes have the same fitness (because of the insufficient alcohol : fields) and some other niches where the fitness of the $A d h^{\mathrm{FF}}$ genotype is greater (because of the existence of sufficient alcohol : wine-cellars) and so, the $A d h^{\mathrm{F}}$ allele is favoured. This phenomenon is not observed at the Est-6 locus and is slightly apparent at the $\alpha-G p d h$. All these conclusions must be taken with caution because they are based only on the results coming from 3 loci studied in 3 field and 9 Iberian wine-cellar populations. Of course, to verify our conclusions, other analyses are needed in field populations.

Received July 16, 1984.

Accepted March 29, 1985.

\section{References}

Aguade M., Serra L., 1980. Spanish cellar populations of Drosophila melanogaster. I. Study of variability at three different levels : quantitative, chromosomal and molecular. Genetika, 12, 111-120.

Cockerham C.C., 1973. Analyses of gene frequencies. Genetics, 74, 679-700.

Cockerham C.C., Weir B.S., 1977. Digenic descent measures for finite populations. Genet. Res., $30,121-147$.

DagGard G.E., 1981. Alcohol dehydrogenase, aldehyde oxidase and alcohol utilization in Drosophila melanogaster, Drosophila simulans, Drosophila inmigrans and Drosophila buskii. In: Gibson J.B., OAKEShotT J.G. (ed.), Genetic studies of Drosophila populations, 59-74, Australian University Press, Camberra, Australia.

Hickey D.A., McLean M.D., 1980. Selection for ethanol tolerance and $A d h$ allozymes in natural populations of Drosophila melanogaster. Genet. Res., 30, 11-15.

Kimura M., 1979. The neutral theory of molecular evolution. Sci. Am., 241, $\mathrm{n}^{\circ}$ 5, 94-104.

Lr C.C., 1955. The stability of an equilibrium and the average fitness of a population. Am. Nat., 89, 281-296.

LeVENE H., 1953. Genetic equilibrium when more than one ecological niche is available. Am. Nat., 87, 311-313.

Lewontin R.C., 1974. The Genetic Basis of Evolutionary Change, 232-239, Columbia University Press, New York and London.

Lewontin R.C., Ginzburg L.R., Tuluapurkar S.D., 1978. Heterosis as an explanation for large amounts of genetic polymorphism. Genetics, 88,, 149-170.

MalpiCa J.M., Vasallo J.M., 1980. A test for the selective origin of environmentally correlated allozyme patterns. Nature, 286, 107-108.

O'Brien S.J., McInTYRE R.J., 1969. An analysis of gene enzyme variability in natural populations of Drosophila melanogaster and Drosophila simulans. Am. Nat., 103, 97-113.

O'Brien S.J., McINTYRe R.J., 1972. The $\alpha$-glycerophosphate in Drosophila melanogaster. II. Genetic aspects. Genetics, 71, 127-138. 
Parsons P.A., 1980. Larval responses to environmental ethanol in Drosophila melanogaster: variation within and among populations. Behav. Gen., 10, 183-190.

Pieragostini E., Sangiorgi S., Giorgi G., Cavicchi S., 1981. Mimicry of isozyme adaptative advantage by gene association. I. Relationships between $A d h$ genotypes and body dimension in Drosophila cage populations: a multivariate analysis. Genetica, 56, 27-37.

Poulik M.D., 1957. Starch gel electrophoresis in a discontinuous system of buffer. Nature, 1180, $1477-1479$.

WeIR B.S., 1979. Inferences about linkage disequilibrium. Biometrics, 35, 235-254.

Wright S., 1969.. The Theory of Gene Frequencies, 190-344, The University of Chicago Press, Chicago. 